\title{
NEVE EFETIVA OU APENAS REFERÊNCIA? RELAÇÃO ENTRE NEVE E FLUXO TURÍSTICO A GRAMADO(RS)
}

\author{
NIEVE REAL O SOLO REFERENCIA? \\ RELACIÓN ENTRE NIEVE Y FLUJO TURÍSTICO A GRAMADO(RS) \\ EFFECTIVE SNOW OR JUST REFERENCE? \\ RELATIONSHIP BETWEEN SNOW AND TOURIST FLOW TO \\ GRAMADO/RS
}

\begin{abstract}
Erika Collischonn
Doutora em Geografia e Professor no Curso de Graduaçáo e no Programa de Pós-Graduação em Geografa da Universidade Federal de Pelotas; ecollischonn@gmail.com
\end{abstract}

Cemila Pansera

Geógrafa pela Universidade Federal de Pelotas; cemilap@gmail.com

\begin{abstract}
Resumo: Gramado é o polo turístico do estado do Rio Grande do Sul. Apresenta um clima subtropical úmido $(\mathrm{Cfb})$, com invernos nos quais são frequentes temperaturas abaixo de 0 ${ }^{\circ} \mathrm{C}$ e geadas, havendo também possibilidade de ocorrência de neve. $\mathrm{O}$ estudo realizado faz uma comparação entre a ocorrência de neve e o fluxo turístico em Gramado (RS). Foram usados os dados da estação meteorológica automática (INMET) de Canela (RS), registrados para os períodos de outono/inverno dos anos de 2009 a 2012. Para o mesmo período foram também obtidos e organizados dados do fluxo de veículos das três praças de pedágio que dâo acesso à cidade de Gramado. Os dados diários foram justapostos de forma a poderem ser comparados. Também se analisou os calendários de eventos para o mesmo período. Constatou-se que o fluxo de veículos nas praças de pedágio se relaciona mais com os finaisde-semana ou dias com eventos programados, do que com a neve anunciada ou ocorrida. $\mathrm{O}$ estudo realizando demonstra que, em Gramado, o fenômeno natural "neve" cede cada vez mais lugar ao artefato "neve" resultante do engenho humano.
\end{abstract}

Palavras chave: neve, fluxo veículos, turismo, imagem, natureza artificial.

\begin{abstract}
Located in Rio Grande do Sul state of Brazil, Gramado is an extremely popular tourist destination for Brazilians due to its temperate climate, european architecture, family-friendly activities and ecoturism options. The city has a humid subtropical climate $(\mathrm{Cfb})$, with winter seasons that are often rigorous with temperatures below $0{ }^{\circ} \mathrm{C}$, leading to the occurrence of severe frost and the possibility of snow. The study aims to relate the occurrence of snow and the touristic flow in Gramado (RS). The data from the meteorological
\end{abstract}


station of Canela (RS) (temperature, dew point, humidity and precipitation) were used, and observed during the month of June to September in 2009-2012 (INMET). For the same period, vehicles' data flow from all toll locations with access to the city of Gramado (BRITA RODOVIAS S.A). It was found that the flow of vehicles at toll locations relate more to weekends and scheduled events, than to snow that had been forecasted or that ended up occurring. The study shows that, in Gramado, the natural phenomenon "snow" gives way more and more to the "snow" artifact resulting from human production.

Keywords: Snow, vehicle flow, image, tourism, artificial nature.

\section{INTRODUÇÃO}

A temática da neve no Brasil ainda não possui quantidade significativa de trabalhos científicos publicados quando comparado com os estudos de outros elementos do clima (ex: temperatura, precipitação pluvial, vento). Isto ocorre porque, segundo Fuentes (2009, p. 20), em fenômenos meteorológicos cuja escala de ocorrência no tempo e no espaço é restrita, mais difícil a sua previsão e o seu registro. Ainda assim, os estudos acerca da neve ganharam fôlego a partir dos anos 1990, principalmente considerando o apelo turístico de municípios do sul do Brasil que ostentam a neve como um atrativo, tais como Gramado no Rio Grande do Sul.

Este estudo busca analisar a relação entre a ocorrência de neve e o fluxo turístico na cidade de Gramado. Assim, por um lado, procurou organizar sistematicamente os dados de precipitaçáo de neve ocorrida em Gramado de 2009 a 2012, tanto os registros de previsão ou neve ocorrida segundo os meios de comunicação, quanto a condição propícia à neve pelos registros da estação meteorológica mais próxima. Estes dados foram comparados com os dados de fluxo de veículos nas praças de pedágio que levam a este destino turístico. Por outro lado, considerou também o quanto outros fatores possivelmente influenciaram nestes fluxos.

O turismo, atualmente, demanda esforços interligados e interdependentes dos órgãos oficiais de turismo, das associações do setor turístico, dos transportadores, dos meios de hospedagem, das agências de viagem, dos parques temáticos, dos restaurantes e, principalmente, da comunidade. Barreto Filho (1999, p. 74-82) considera como elementos fundamentais para o desenvolvimento do turismo receptivo de um determinado espaço urbano algumas estratégias: conscientização turística, preparação de recursos humanos, criação de um órgão oficial de turismo, dotação orçamentária, elaboração de um calendário de eventos turísticos, guia básico de informaçóes turísticas, sinalização turística, delimitação dos roteiros turísticos, liberação do horário comercial, proteção do ambiente, promoção e divulgação nos polos emissores, estatísticas de análise dos resultados, ampliação de espaços e desenvolvimento de novos produtos. 
Assim, uma cidade turística como Gramado, depende hoje do encadeamento bem planejado destas açóes, e o trade turístico ${ }^{1}$ náo pode ficar à mercê da ocorrência de um fenômeno natural esporádico. Na medida em que o estudo foi se realizando, aos poucos foi se revelando como, em Gramado, o fenômeno natural "neve" cede cada vez mais lugar a "neve" como artefato, memória ou simulação.

\section{O FENÔMENO ATMOSFÉRICO NEVE E A LOCALIZAÇÃO DE GRAMADO (RS)}

O glossário do INMET define a neve da seguinte forma:

Precipitação de cristais de gelo translúcidos e brancos, em geral em forma hexagonal e complexamente ramificados, formados diretamente pelo congelamento do vapor de água que se encontra suspenso na atmosfera. É produzida frequentemente por nuvens do tipo estrato, mas também pode se originar das nuvens do tipo cúmulo. Normalmente os cristais são agrupados em flocos de neve.

Nery e Carfan (2013, p. 252) e Schmitz (2007, p. 4) apresentam conceituação similar, porém acrescentam que os cristais em forma de estrela somente se formam em temperaturas abaixo de $-5{ }^{\circ} \mathrm{C}$, já nas temperaturas próxima ao $0{ }^{\circ} \mathrm{C}$ os cristais geralmente se aglomeram em flocos de neve.

Como as outras formas de precipitação (chuva e granizo), a neve, corresponde a uma etapa do ciclo hidrológico. Entretanto para chegar a superfície terrestre, este hidrometeoro depende de algumas circunstâncias que serão apresentadas a seguir.

A existência de nebulosidade é uma condição fundamental para a gênese da precipitação. Para tanto a umidade e os núcleos de condensação funcionam como matérias-primas e a movimentação vertical do ar como motor do processo de formação de nuvens. Todas as nuvens produtoras de precipitação têm sua gênese associada a movimentos ascendentes do ar. Estes podem ser induzidos por três meios (que atuam em articulação ou isolados): aquecimento basal (convecção), orografia e advecção (BATTAN, 1987).

A advecção de ar frio de um lado, a injeção de umidade de outro e, por fim a orografia propiciam a ocorrência de neve na área de estudo (Gramado $(\mathrm{RS})$ ). A presença de uma massa polar sobre o continente, resulta na advecção de ar frio, já a morfologia do Planalto Meridional reforça a ascensão do ar e seu resfriamento. Estes dois fatores conjugados, contudo, propiciam mais a geada do que a neve, porque a massa de ar polar continentalizada é fria e seca. Então, a estes dois fatores precisa se agregar outro, qual seja, a presença de um ciclone extratropical sobre o oceano que impulsione umidade para a serra gaúcha.

São organizaçôes privadas e governamentais atuantes no setor de "Turismo e Eventos" como os Hotéis, Agências de Viagens especializadas em Congressos, Transportadoras Aéreas, Marítimas e Terrestres, além de Promotores de Feiras, Montadoras e Serviços Auxiliares (tradução simultânea, decoração, equipamentos de áudio visuais, etc.) (EMBRATUR, 1995) 
Em geral, as gotículas ou mesmo cristais de gelo que constituem as nuvens são pequenas, de maneira que não vencem a ascensão do ar ou então vaporizam-se na trajetória descendente. A literatura meteorológica apresenta dois processos para o crescimento das gotículas: coalescência e formação de cristal de gelo, este último responsável pela maior parte das precipitaçóes nas latitudes médias no inverno (VIANELLO e ALVEZ, 1991). É a partir deles que ocorre a formação da neve, descrita a seguir.

O processo dá-se nas “nuvens frias”, ou seja, aquelas situadas em níveis atmosféricos com temperatura inferior a $0{ }^{\circ} \mathrm{C}$. Nestas condiçôes a tensão de vapor saturante é menor para o gelo que para a água em estado líquido. Assim, se existirem simultaneamente numa "nuvem fria" gotículas de água e cristais de gelo, as moléculas que constituíam a gotícula juntam-se ao cristal de gelo, que assim cresce à custa daquelas (VIANELLO e ALVEZ, 1991).Os cristais vão ganhando massa e colidindo uns aos outros. Os cristais imbricados que chegam ao solo constituem a neve, que pode atingir uma velocidade terminal de 1 a $2 \mathrm{~m} / \mathrm{s}$ (BATTAN, 1989).

O fenômeno em análise é mais complexo que o da precipitação líquida, especialmente pela participação do vento que pode vir a movimentar os flocos de neve. Com base nisto, Souza (1997) identifica que, entre os parâmetros básicos para a medição da neve — dias de neve, altura da camada, tempo de permanência sobre o solo e equivalente em água o primeiro é o único medido sistematicamente pelo INMET no Brasil, sendo o total de dias com queda de neve em um período determinado, como um mês e/ou ano.

Araujo (1930) e Hausman (1956) nos seus escritos sobre a climatologia do Rio Grande do Sul, apresentaram algumas linhas ou parágrafos destinados à neve. Em 1991, Souza publicou um artigo sobre a neve no sul do Brasil. Vale ainda mencionar os trabalhos de Schmitz (2000) e Wolff (2001). Wolff, em 2005, publicou livro com resultados do trabalho desenvolvido em 2001, contendo um importante histórico da neve no RS. Observa-se, portanto que tem crescido, nas últimas duas décadas, a produção científica sobre os eventos de neve ou frio intenso, talvez pela área de abrangência e suas consequências na economia regional, seja na agropecuária, ou nas atividades turísticas.

Considerando este elemento do clima nos estados do Rio Grande do Sul e Santa Catarina, Souza (1997) propôs a definição do que chamou Planalto da Neve. Schmitz (2007, p. 36) delimitou com mais acurácia metodológica o chamado Planalto da Neve que seria a área do Meridional com cota superior a $600 \mathrm{~m}$, ou seja, a área onde este fenômeno ocorre (Figura 1). Neste planalto da Neve, Schmitz (2007) definiu dois setores: I - acima da cota de $900 \mathrm{~m}$ no qual o número médio de dias de neve por ano considerando a normal climatológica 1961- 1990 seria maior que 1 e II - entre as cotas 600 e $900 \mathrm{~m}$ e aquele onde o número médio de dias de neve por ano considerando a normal climatológica 1961- 1990 seria menor que 1 .

O município de Gramado que está localizado a 290 22' 44"S e 50 52' 26" W, apresentando uma superfície total de $237,019 \mathrm{~km}^{2}$ (IBGE, 2013). Segundo a compartimentação de Schmitz (2007), Gramado tem sua sede e 64 \% do seu território no setor II, o menos nivoso; da mesma forma Canela, também tem $70 \%$ do seu território no setor II. 
Figura 1 - Localização do Planalto da Neve e seus setores diferenciados

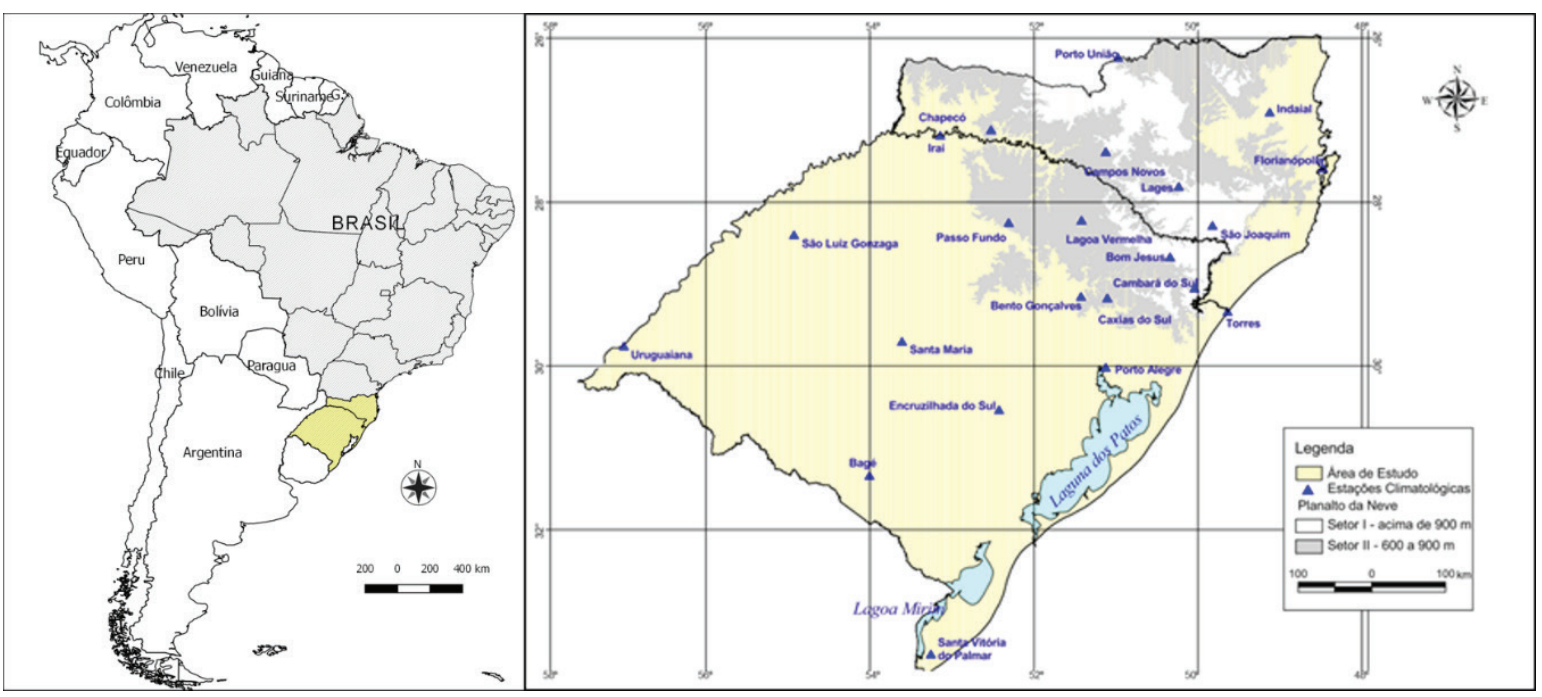

Fonte: Schmitz, 2007, p. 37

Na divisão turística do Rio Grande do Sul definida pela SETUR, Gramado, com uma população de 32.501 habitantes em 2011 (FEE, 2013) encontra-se na Região Turística das Hortênsias que é composta por cinco municípios: Canela, Gramado, Nova Petrópolis, Picada Café e São Francisco de Paula (Figura 2).

Figura 2 - Localização de Gramado (RS)

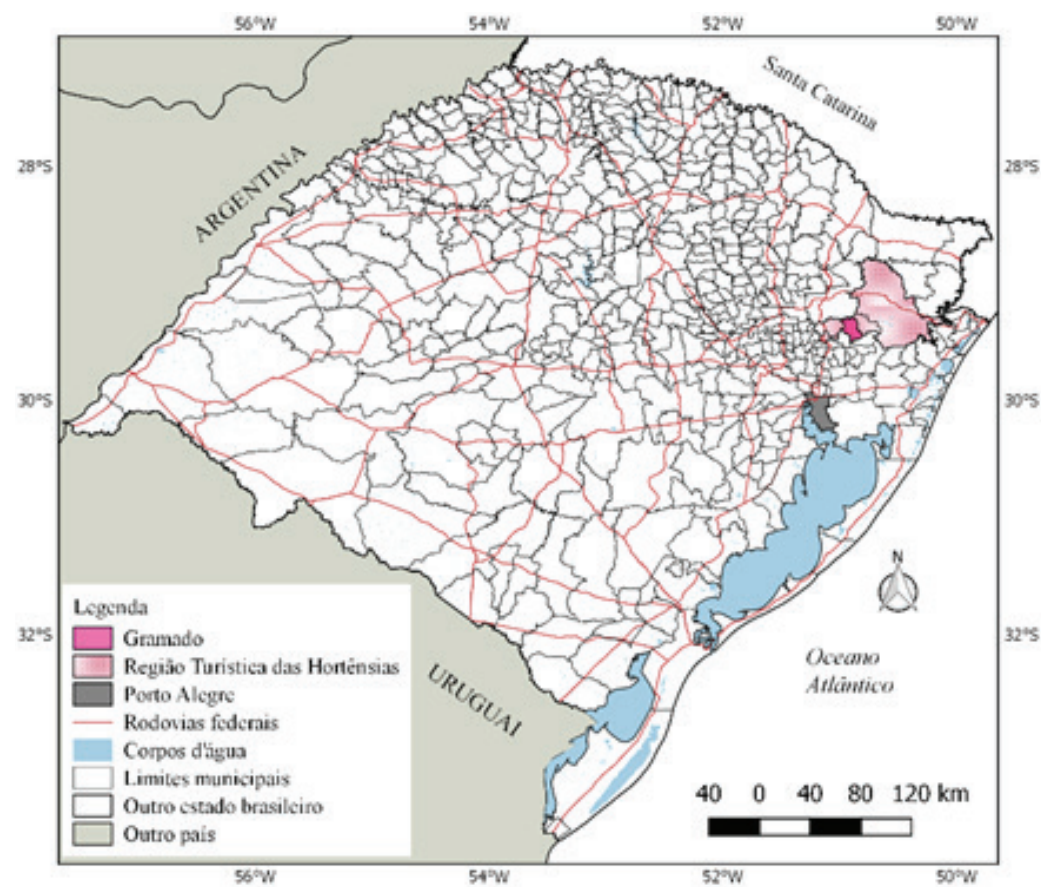

Fonte: Organizado pelas autoras, 2017. 


\section{METODOLOGIA}

Para Santana Neto (2002, p. 327) ao geógrafo, mais do que desvendar os processos dinâmicos e as estruturas temporais e espaciais do clima, o que realmente deveria importar é o significado deste processo inserido na dimensão socioeconômica.

$\mathrm{Na}$ perspectiva deste autor, numa análise geográfica dever-se-ia identificar os sistemas produtores do tempo e, em análises episódicas, explicar como, onde e por que ocorreu, por exemplo, precipitação de neve num determinado espaço, mas também dever-se-ia indagar, compreender e explicar como e em quais circunstâncias este espaço foi produzido e como as precipitaçóes de neve e o frio afetam, de forma diferenciada os seus habitantes e a sua economia. Por fim, para Santana Neto, um geógrafo deveria procurar compreender, ainda, de que forma este processo da natureza é apropriado em sua forma mais intensa e perversa pela sociedade de classes.

Em síntese, a climatologia na análise geográfica, não pode ficar desconectado da realidade social. O conhecimento do ritmo climático deve ser incorporado ao conjunto de conhecimentos geográficos necessários à compreensão da dinâmica territorial e da apropriação da natureza.

Esta foi a perspectiva de método buscada neste trabalho, ainda que não se tenha dado conta da representação da circulação atmosférica geradora dos estados de tempo com neve. $\mathrm{O}$ estudo foi realizado em quatro etapas. A primeira etapa trata de uma breve avaliação da evolução do turismo em Gramado. A segunda analisa dados meteorológicos horários da estação automática do INMET instalada no município de Canela, com ênfase nas temperaturas propícias à ocorrência de neve. A terceira avalia a frequência de fluxos nas praças de pedágio próximas à Gramado. Por fim, o estudo trata da conclusão e apresentação dos resultados.

O levantamento de dados sobre turismo e história da cidade Gramado (RS), foi realizado com base bibliográfica de livros, dissertaçóes, monografias, além de artigos e reportagens também obtidos em modo eletrônico. Foram utilizados também os calendários de eventos da cidade no período de 2009 a 2012.

Neste estudo utilizaram-se os dados gráficos da estação automática da cidade de Canela (RS), pelo fato de náo haver estaçáo meteorológica do INMET na cidade de Gramado. A estação automática de Canela foi instalada em 23/08/2008 e está localizada a $29.3688^{\circ} \mathrm{S}$ e $50.8274^{\circ} \mathrm{WGr}$ e altitude $830 \mathrm{~m}$. Esta estação dista sete quilômetros do centro de Gramado e em altitude similar.

Os dados do período 01/01/2009 a 31/12/2012 foram obtidos no banco de dados do INMET. Destes anos foram selecionados apenas os meses de maio a setembro, quando as temperaturas são mais baixas, propícias à ocorrência de neve. $\mathrm{O}$ sistema não permite baixar os dados numéricos, mas gera gráficos dos quais foi possível extrair por datas, temperaturas menores ou iguais a $5^{\circ} \mathrm{C}$, além da umidade relativa do ar, precipitaçáo e ponto de orvalho. Assim, os dados foram organizados a partir da leitura dos gráficos.

Para se deslocar até Gramado, a maior parte dos turistas passa com o veículo que os transporta por uma das praças de pedágio da Regiáo das Hortênsias, tendo em vista 
que não há aeroporto em Gramado (Figura 3). Os aeroportos mais próximos são os de Canela, Caxias do Sul e Porto Alegre. O primeiro recebe avióes de pequeno porte e particulares, tendo um fluxo restrito que não foi contabilizado nos dados de fluxo neste trabalho. O segundo e o terceiro aeroporto são mais distantes de Gramado e, obrigatoriamente, o turista vindo destes aeroportos terá que passar por uma das praças de pedágio.

Figura 3 - Croqui com localização das praças de pedágios na Região das Hortênsias

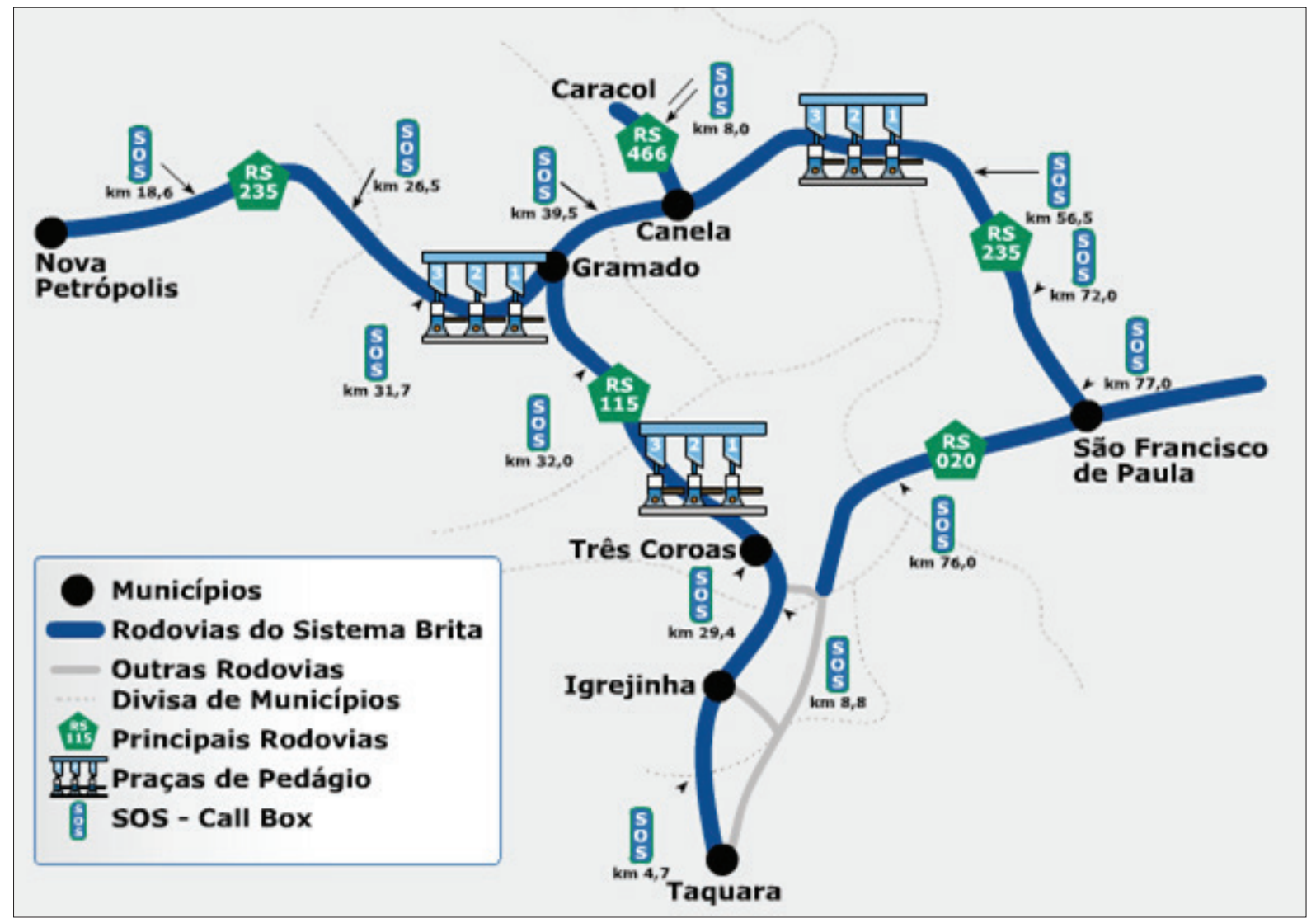

Fonte: Brita Rodovias, 2013

Na sequência, procedeu-se o levantamento dos dados de fluxo obtidos junto à Brita Rodovias S.A, responsável pelas três praças de pedágios que cercam Gramado. Os dados de fluxo de passantes pelo pedágio foram obtidos para todos os meses dos anos de 2009 a 2012. Isto facilitou a análise dos dados relativos ao período com possibilidade de ocorrência de neve (junho a setembro) no contexto anual.

Os dados das três praças foram somados e, em seguida, organizaram-se os dados de fluxo de veículo em gráficos para cada um dos meses de inverno de 2009 a 2012. Para compreender a relação entre fluxo de veículos e possibilidade de neve realizou-se a representação concomitante dos gráficos de fluxo de veículos em unidades de tempo cronológico diárias juntamente com os dados tabelados dos elementos fundamentais do 
clima que propiciam a ocorrência de neve. Para facilitar a análise, além do dia do mês, também foi indicado o dia da semana.

Por fim, foi considerada a previsão anunciada de neve por um dos jornais de maior circulação no Rio Grande do Sul. Os dados foram retirados do histórico online do jornal Zero Hora, considerando-se os anos de 2010 a 2012 e listados (Quadro 1).

\section{Tabela 1 - Previsão ou ocorrência de neve para o período 2010-2012, segundo o arquivo do jornal Zero Hora}

\begin{tabular}{|l|c|}
\multicolumn{1}{|c|}{2009} \\
\hline 01/jun & NEVE \\
\hline 02/jun & previsão \\
\hline 10/jun & previsão \\
\hline 11/jun & previsão \\
\hline 23/jun & previsão \\
\hline 24/jun & previsão \\
\hline
\end{tabular}

\begin{tabular}{|c|c|}
\multicolumn{2}{|c|}{2010} \\
\hline 14/jul & previsão \\
\hline 03/jun & previsão \\
\hline 04/jun & NEVE \\
\hline 13/jun & previsão \\
\hline
\end{tabular}

\begin{tabular}{|c|c|}
\multicolumn{2}{c|}{2011} \\
\hline 25/jun & previsão \\
\hline 26/jun & previsão \\
\hline 02/jul & previsão \\
\hline 31/jul & previsão \\
\hline 02/ago & previsão \\
\hline 03/ago & NEVE \\
\hline 04/ago & NEVE \\
\hline 19/ago & previsão \\
\hline
\end{tabular}

\begin{tabular}{|c|c|}
\multicolumn{2}{|c}{2012} \\
\hline 04/jun & previsão \\
\hline 07/jun & previsão \\
\hline 08/jun & previsão \\
\hline $10 / j u l$ & previsão \\
\hline $12 / j u l$ & previsão \\
\hline $24 /$ set & previsão \\
\hline $25 /$ set & previsão \\
\hline $26 /$ set & previsão \\
\hline
\end{tabular}

Fonte: Jornal Zero Hora, adaptado pelas autoras.

\section{RESULTADOS - FLUXO DE VEÍCULOS E TURISMO DE INVERNO ENTRE 2009 E 2012}

Nesta seção serão apresentados os gráficos mês a mês, do fluxo de veículos diários nas praças de pedágio, aos quais foram sobrepostos ícones de flocos de neve, segundo a seguinte classificação: em preto, para os dias propícios a neve ou prevista, ou um floco de neve em vermelho, para a neve efetivamente registrada. Tal ordenação objetivou avaliar a eficiência do fenômeno atmosférico - neve - no fluxo de veículos que passaram pelo pedágio.

Apesar de ser considerada possível a ocorrência de neve no mês de maio, em nenhum dos anos do período analisado as temperaturas foram suficientemente baixas para tanto. Em alguns meses do período considerado também não houve registros de temperatura suficientemente baixa para possibilitar neve.

Na Figura 4, apresenta-se a sequência, por dia da semana, dos dados de fluxo de veículos (pesados e leves empilhados na coluna), da ocorrência de neve e de dias propícios à neve ou de dias que a imprensa tenha previsto o fenômeno no ano de 2009 (indicado pelo ícone da neve). 
Figura 4 - Fluxo de veículos nas Praças de Pedágio próximas a Gramado em junho a setembro de 2009
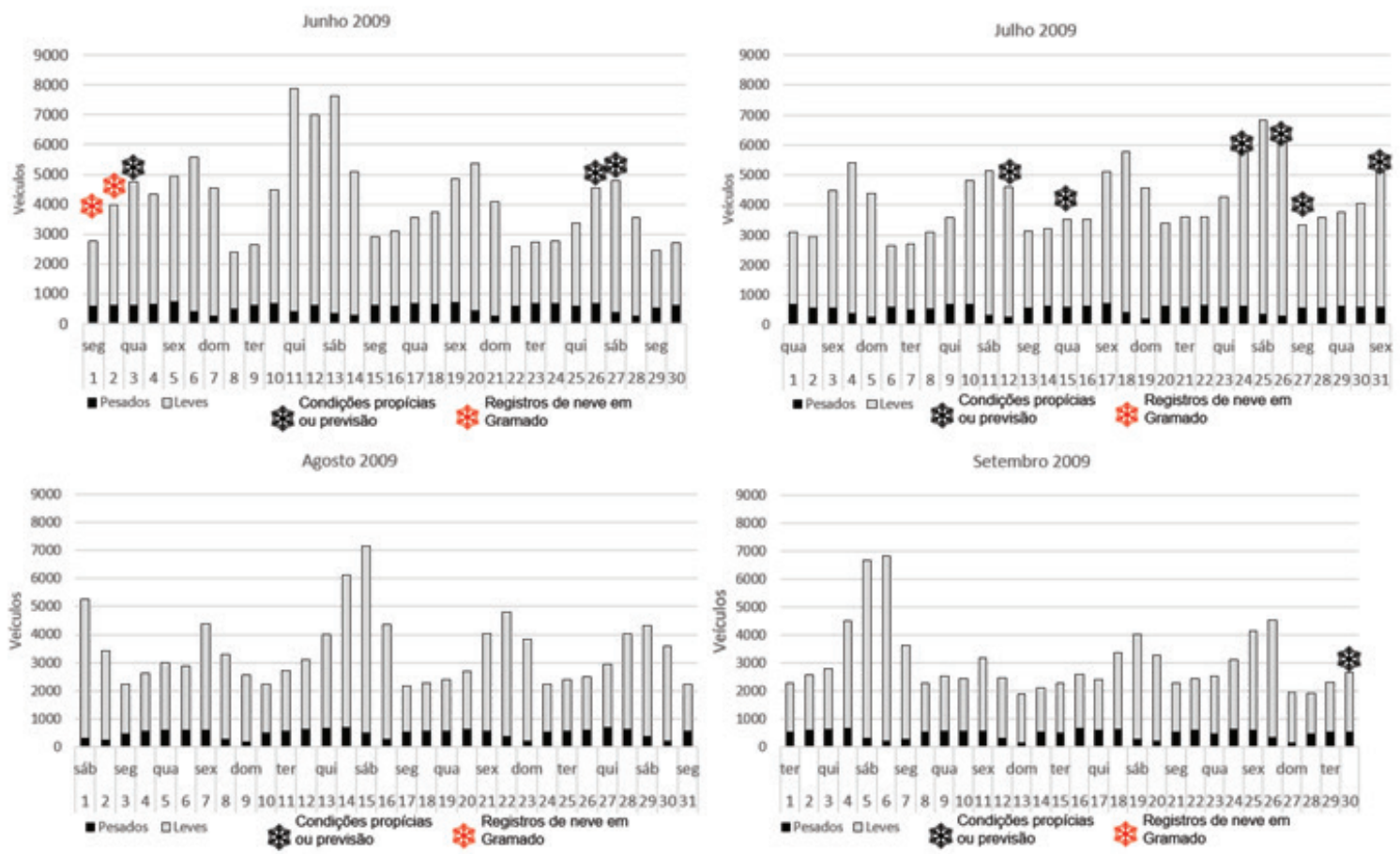

Fonte: INMET - Estação Meteorológica de Canela; Brita Rodovias S.A e Arquivo Zh.

O gráfico de junho de 2009 mostra que a ocorrência de neve Dia $1^{\circ}$ e 2 de junho, de segunda à quarta, coincide com o maior fluxo de veículos para estes dias da semana em todo o mês; porém os maiores fluxos de veículos do mês ocorreram nos finais de semana e, principalmente, no período compreendido entre os dias 10 e 14 . Este crescimento está ligado ao feriado de Corpus Christi, dia 11, o Dia dos Namorados, dia 12, e eventos relacionados no período, como o Festival Mundial de Publicidade de Gramado e o Congresso de Educação. Outros dias que apresentaram temperaturas propícias à neve foram os dias 26 e 27, sexta e sábado, dias que tiveram o maior fluxo de veículos nesta semana que, no entanto, foi a de menor fluxo no mês. O fluxo total mensal de passantes no pedágio em julho foi de 125.175 veículos.

Julho de 2009 apresentou ligeiro aumento no fluxo total, com 129.144 veículos, e a distribuição ao longo do mês manteve um padrão, com fluxos maiores nos finais de semana (de sexta a domingo).A partir de meados do mês, houve um ligeiro aumento de fluxo de veículos, mesmo durante a semana, em função da correspondência com as férias escolares e o Festival de Inverno. Além disso, os dias de frio intenso sucessivos ocorreram entre 24 e 27 . O dia 24 , que foi uma sexta feira, assim como o sábado e o domingo subsequente, foram os dias de tráfego mais intenso neste mês.

O mês de agosto de 2009 não apresentou temperaturas que propiciassem à ocorrência de neve. O total mensal de passantes no pedágio diminuiu em relação a julho, com 105.806 veículos. O fluxo durante a semana voltou a ficar menor em relaçáo 
à segunda quinzena de julho, contudo o padráo de fluxo alto no fim de semana se manteve. O 37. ${ }^{\circ}$ Festival de Cinema de Gramado é o grande responsável pelo maior fluxo do mês no período dos dias 9 a 15, este último sendo o dia em que se registrou o maior fluxo.

Em setembro de 2009, o dia 30 foi o único a apresentar temperatura menor que $5{ }^{\circ} \mathrm{C}$ no mês. $\mathrm{O}$ ápice de fluxo de veículos, no entanto ocorreu no período dos dias 4 a 7, fim de semana prolongado em função do feriado da Independência, ocorrido na segunda feira. O fluxo total de veículos do mês foi o menor do inverno, com 92.100 veículos.

Em termos de movimento anual nos pedágios (Figura 5), constatou-se que houve um aumento no fluxo de veículos leves nos meses de inverno de 2010, com um máximo em julho, porém, o fluxo mais intenso de veículos nos pedágios do entorno de Gramado (156.103 veículos), ocorreu em dezembro, mês central do "Natal Luz", evento que ocorre do fim de outubro a meados de janeiro.

Figura 5- Fluxo mensal de veículos nas praças de pedágio em 2009

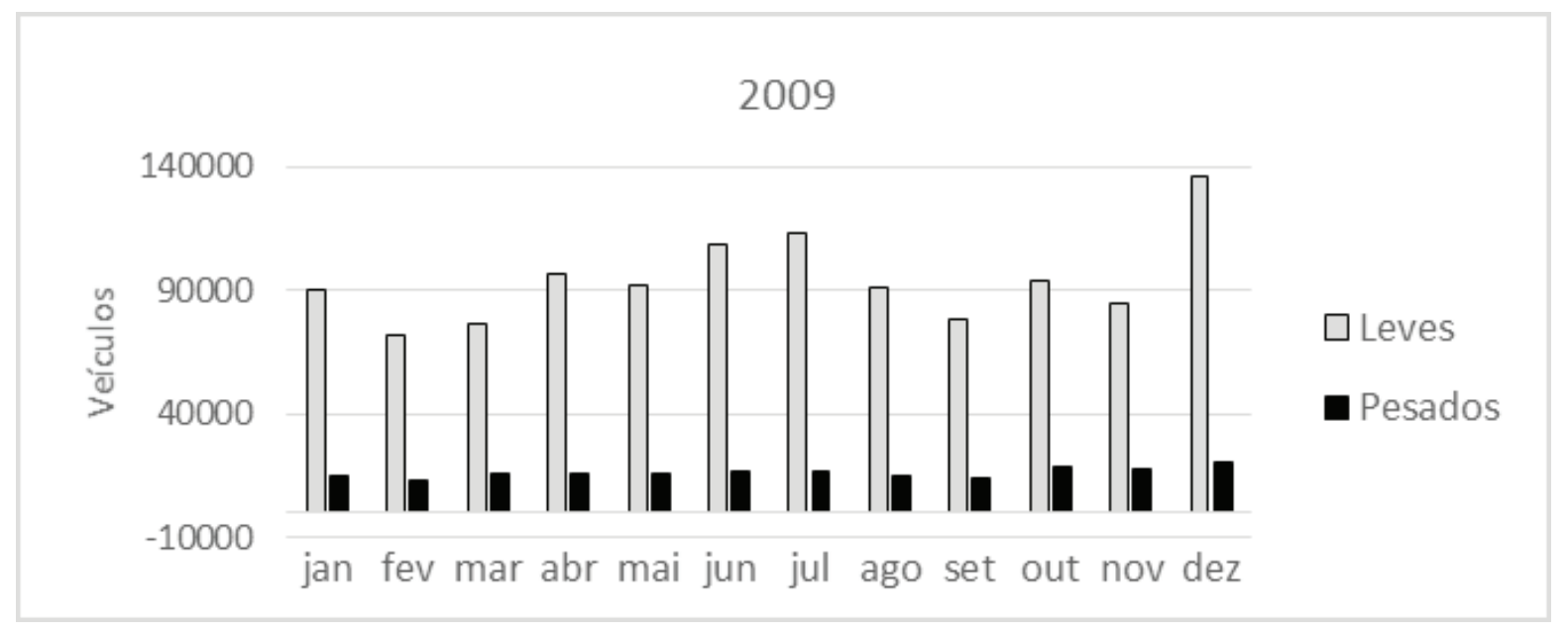

Fonte: Brita Rodovias

Na figura 6, apresenta-se a sequência, por dia da semana, dos dados de fluxo de veículos, registro de neve ou de dias propícios ao fenômeno no ano de 2010. 


\section{Figura 6 - Fluxo de veículos nas Praças de Pedágio próximas a Gramado de junho a setembro de 2010}
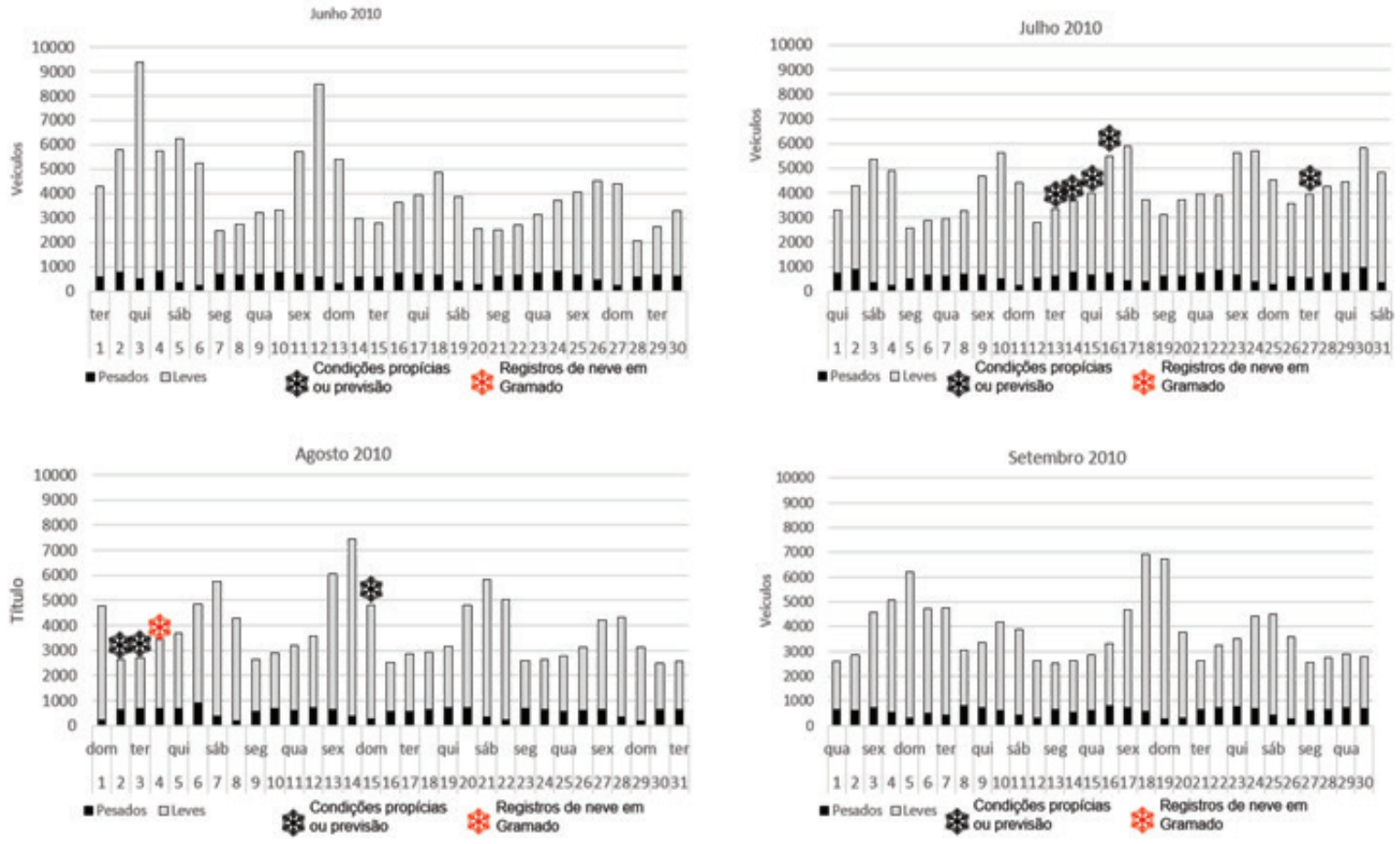

Fonte: INMET - Estação Meteorológica de Canela; Brita Rodovias S.A e Arquivo Zh.

Em junho de 2010 não se registrou ocorrência de dias de frio intenso. O grande destaque é o dia 3, uma quinta-feira com grande fluxo de veículos, correspondente ao início do evento "Saláo Internacional do Calçado". No sábado dia 12, o grande fluxo de veículos refletiu a passagem dos enamorados por Gramado, dada a aura de romantismo que se criou em torno deste polo turístico. No total, 125.581 veículos passaram pelos pedágios do entorno de gramado neste mês.

Em julho de 2010 ocorreram vários dias seguidos de baixas temperaturas, mesmo assim não houve registro de neve. Apesar de ser o mês de férias escolares, o fluxo de veículos foi similar ao ano anterior (130.445 veículos), mas distribuído ao longo de todo o mês, com ligeiros aumentos de fluxo nos finais de semana. Nos dias 13 a 16 a temperatura se mantém inferior a $5^{\circ} \mathrm{C}$, com previsão de neve Dia 14 , resultando um aumento do fluxo no fim de semana do dia 17 e 18 .

Em agosto de 2010, foi registrada neve no Planalto da Neve nos dias 2, 3 e 4 de agosto. Em Gramado, registros fotográficos mostraram a ocorrência dia 4.Apesar disso, náo houve aumento substantivo do fluxo no final de semana subsequente (7 e 8).Dia 13 ouve previsão de neve, mas a temperatura caiu dia 15 e náo ocorreu neve. O fim do Festival de Cinema de Gramado (6 a 14), como no ano anterior, volta a ser o responsável pelo maior fluxo do mês. O fluxo total mensal nos pedágios foi de 117.679 veículos. 
Em setembro de 2010, não houve registro de temperaturas propícias à neve e fluxo do mês é padrão, com um aumento nos finais de semana e um fluxo total mensal de 113.928 veículos passantes nos pedágios.

Em termos de movimento anual nos pedágios, constata-se através da Figura 7, que houve um aumento no fluxo de veículos leves nos meses de inverno de 2010, com um máximo em julho. O fluxo mensal mais intenso de veículos nos pedágios do entorno de Gramado (156.103 veículos) ocorreu no mês dezembro, mês em que ocorre o auge do evento "Natal Luz".Nota-se também que, os meses de novembro e janeiro, que abrangem também o período do "Natal Luz" apresentaram altas próximas aos meses de junho e julho.

Figura 7 - Fluxo mensal de veículos nas praças de pedágio em 2010

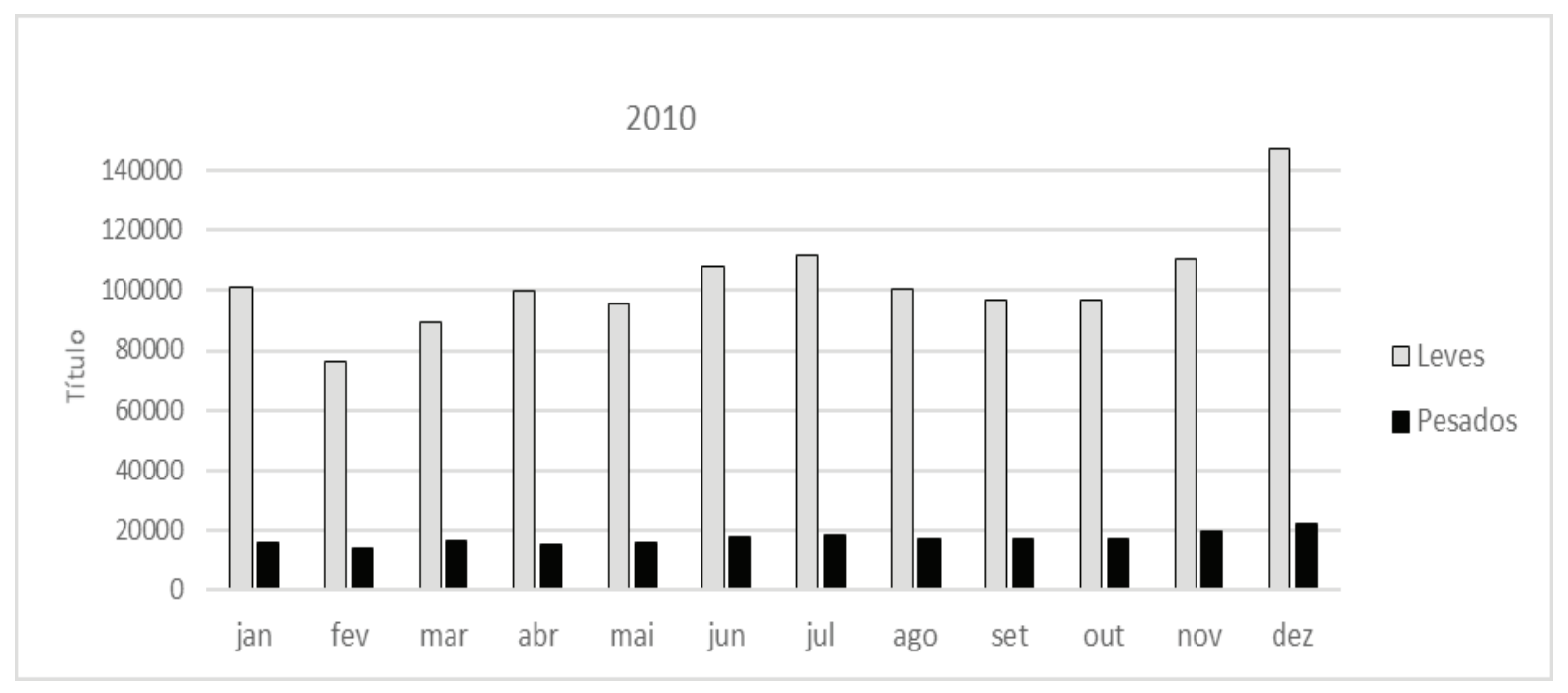

Fonte: Brita Rodovias

$\mathrm{Na}$ Figura 8, apresenta-se a sequência, por dia da semana, dos dados de fluxo de veículos, de ocorrência de neve, previsão ou ainda de condiçóes propícios ao fenômeno no ano de 2011. 


\section{Figura 8 - Fluxo de veículos nas Praças de Pedágio próximas a} Gramado de junho a setembro de 2011
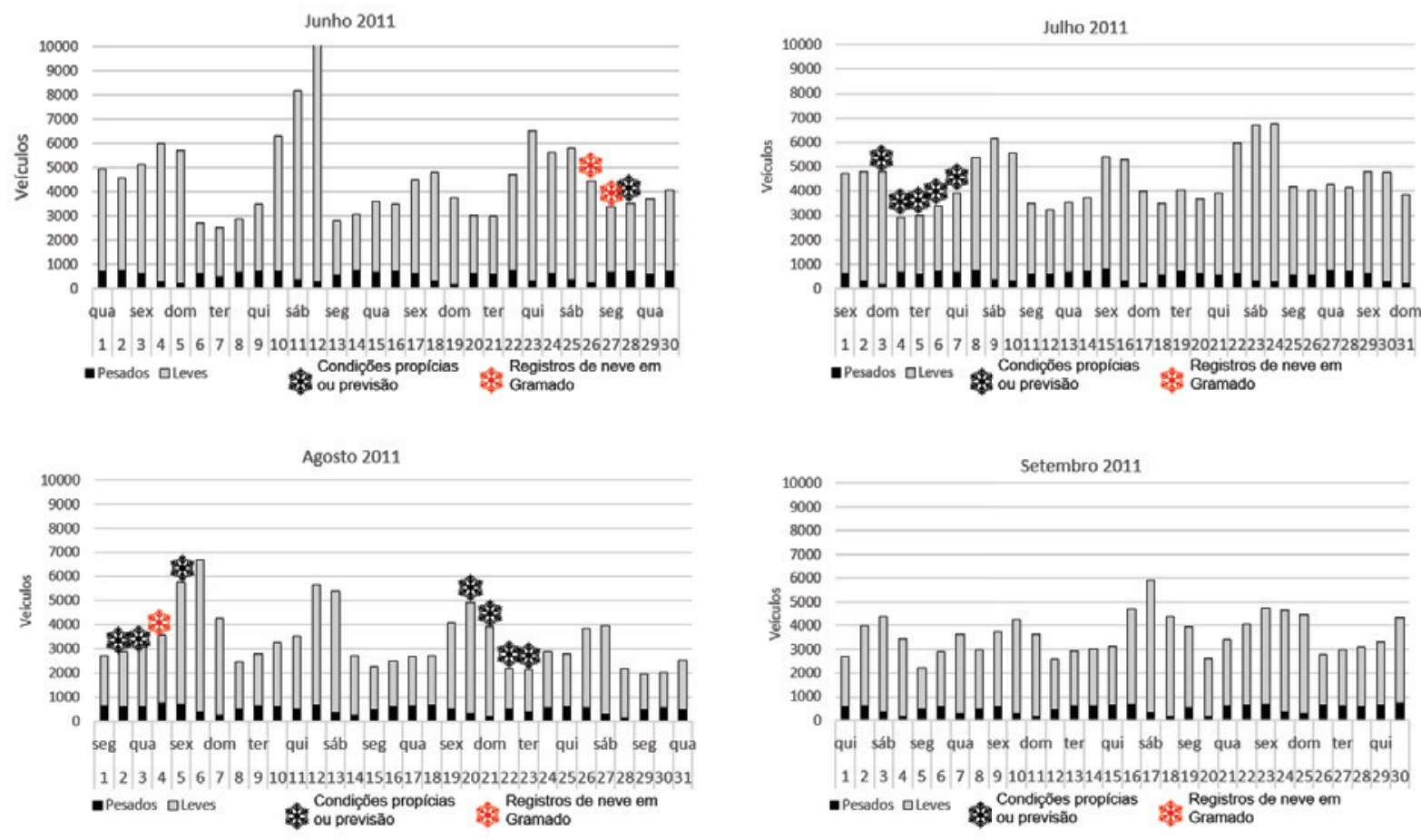

Fonte: INMET - Estação Meteorológica de Canela; Brita Rodovias S.A e Arquivo Zh.

Em junho de 2011, como anunciada a previsão, nevou no domingo 26 e Dia 27. Mesmo assim, não foi este o dia de maior fluxo de veículos. Neste ano, novamente o dia dos Namorados movimenta a cidade, chegando a quase dez mil o fluxo de veículos leves. O feriado de Corpus Christi dia 23, também foi agente responsável para um aumento na semana. Para os dias 25 e 26 houve previsão de neve edia 27 as temperaturas foram mais propícias. O dia 27 foi a segunda-feira mais movimentada do mês nas praças de pedágio. No total, 136.257 veículos passaram pelos pedágios do entorno de gramado neste mês.

Como já observado nos anos anteriores, o fluxo de veículos nos pedágios no mês de julho foi um pouco superior ao mês de junho, com 138.063 veículos no total. O fluxo neste mês foi também mais constante durante a semana, por ser período de férias escolares, com valores mais significativos na segunda quinzena do mês. Do dia 3 ao dia 7, as temperaturas foram propicias a neve e houve previsáo para tal, causando um aumento no fluxo gradativamente no período até o fim de semana. O Congresso Internacional de mobilidade Urbana - 20 a 23, também movimentou a cidade.

Em agosto de 2011, ocorreu previsão de neve para os dias 3 e 4, sendo registrada sua ocorrência em várias cidades do Planalto da Neve, inclusive em Gramado. Entre os dias 3 a 5 as temperaturas foram propícias a ocorrência do fenômeno, proporcionando aos dias 5, 6 e7 (sexta-feira, sábado e domingo) um elevado fluxo de veículos. Este aumento 
de fluxo tem como incremento o fato de ser o quinto dia útil do mês. Ao chamamento para a neve veiculado nos meios de comunicação juntou-se o início do 39. ${ }^{\circ}$ Festival de Cinema, ocorrido de 6 a 13 de agosto neste ano. Para o dia 19 ocorreu previsão de neve e as temperaturas foram propícias a sua ocorrência nos dias 20 e 23, coincidindo justamente com o fim de semana. Mesmo assim, neste fim de semana o fluxo não foi o mesmo dos dois fins de semana que o antecederam. No total, 104.359 veículos passaram pelos pedágios do entorno de gramado neste mês.

Em setembro de 2011 não ocorreram temperaturas propícias à neve, a variação do fluxo turístico no pedágio ocorreu em decorrência de eventos na cidade. $\mathrm{O}$ feriado da Independência ocorreu no meio da semana (quarta-feira), propiciando um fluxo maior que o normal para um dia de semana. O mês apresentou um fluxo total de 108.753 veículos nas praças de pedágio.

Em termos de movimento anual nos pedágios, constata-se através da figura 9, que os meses de junho e julho 2011 estáo entre os de maiores fluxos, porém neste ano também o mês de abril também despontou com valores similares. Neste ano, a páscoa foi relativamente tarde (em 24/04/2011) e a "Chocofest", outro evento tradicional na cidade, provocou um aumento no fluxo de veículos entre os dias 7 a 24 de abril. Mesmo assim, o fluxo mensal mais intenso de veículos nos pedágios do entorno de Gramado (180.905 veículos) ocorreu novamente no mês dezembro, devido ao evento "Natal Luz", que também que fez aumentar os fluxos nos meses de janeiro e novembro.

Figura 9 - Fluxo mensal de veículos nas praças de pedágio em 2011

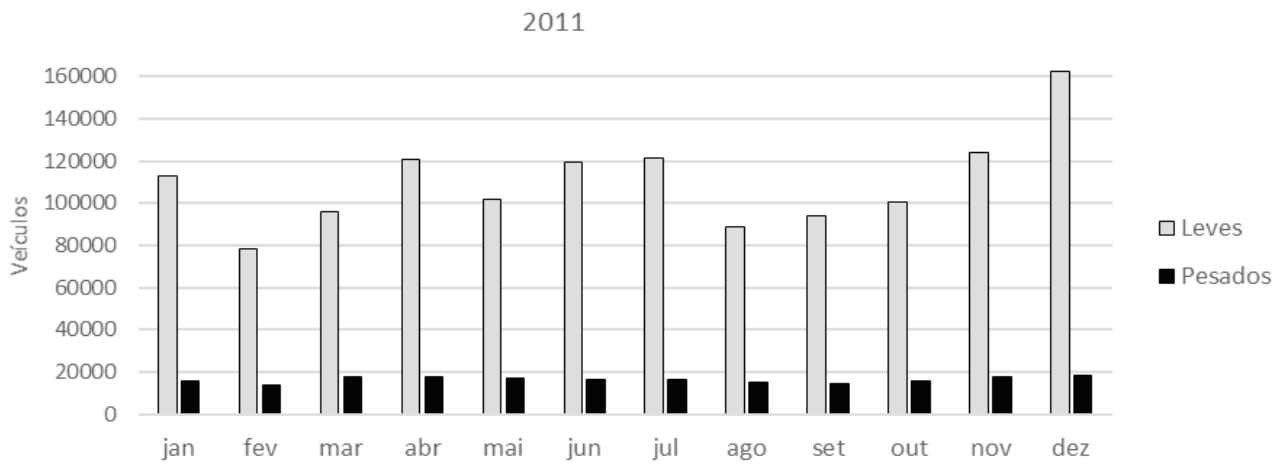

Fonte: Brita Rodovias

Na figura 10, apresenta-se a sequência, por dia da semana, dos dados de fluxo de veículos, de ocorrência de neve, previsão ou ainda de condiçóes propícios ao fenômeno, para os meses frios no ano de 2012.

Em 2012, o mês de junho teve um fluxo turístico maior. Para os dias 4 e 7 houve previsão de neve e, para os dias 7 e 8 , quando as temperaturas realmente despencaram, continuava a previsão. Estas previsóes coincidiram com o Feriadão de Corpus Christi (07/06), definindo o fluxo mais significativo do mês, chegando próximo aos 
dez mil veículos no feriado. Nos dias 10 a 12 a neve foi anunciada pelas previsóes, porém as temperaturas não indicaram. Neste ano, mesmo com a previsão de neve, o "Dia dos Namorados" não fez aumentar o fluxo de veículos, porque a data caiu numa segunda-feira. Afora o feriado de Corpus Christi, o restante do mês o ritmo voltou ao padrão (3.500 veículos/dia no início e 5.500 veículos/dia no fim de semana). O total de veículos passantes nos pedágios do entorno de Gramado para junho de 2012 foi de 146.073 veículos.

\section{Figura 10 - Fluxo de veículos nas Praças de Pedágio próximas a Gramado de junho a setembro de 2012}
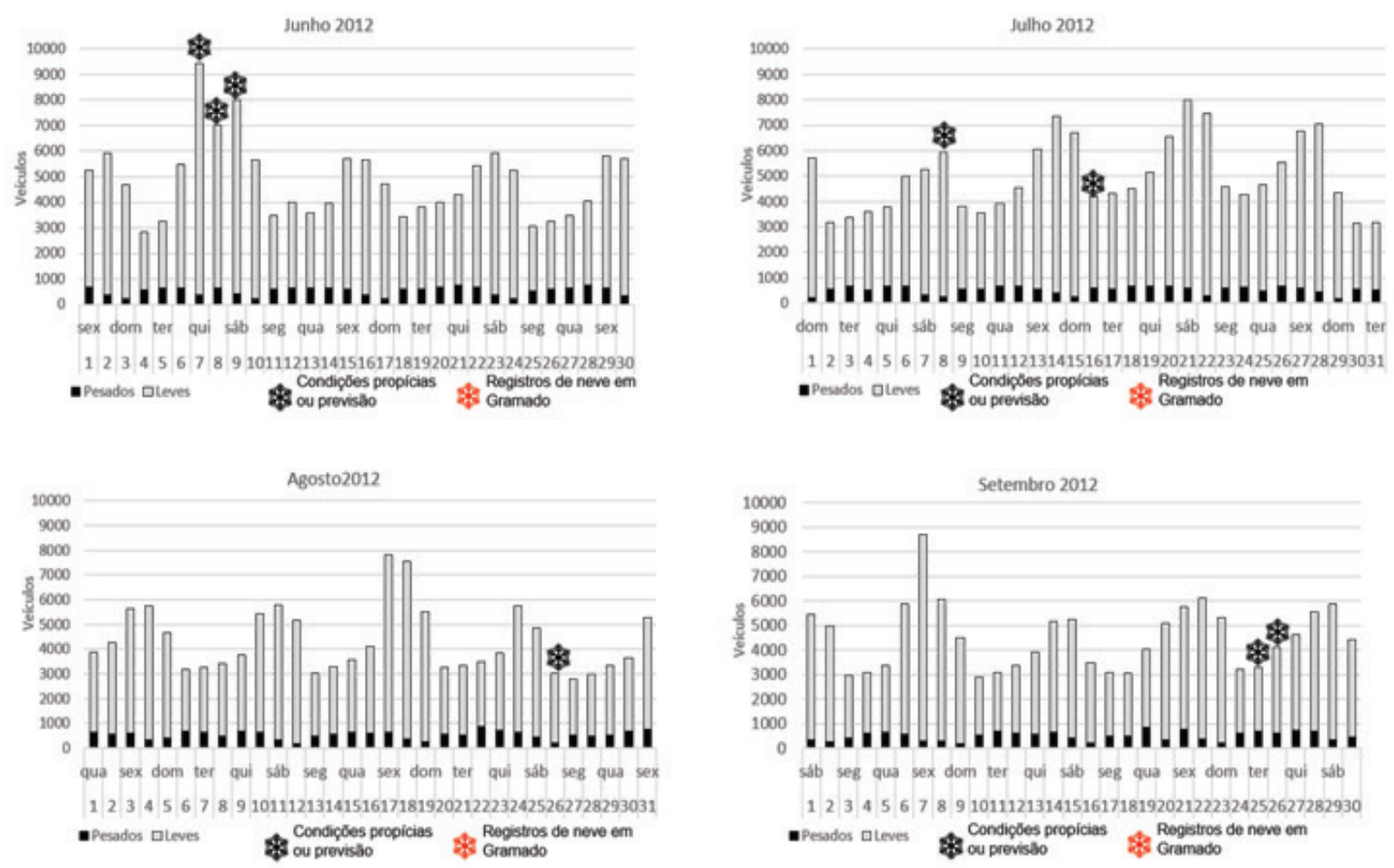

Fonte: INMET - Estação Meteorológica de Canela; Brita Rodovias S. A e Arquivo Zh.

Dia 30 de junho de 2012, iniciou o evento "Estação Gramado" que transcorreu deste dia até 29 de julho. Pode-se observar que durante o período deste evento, somente dois dias apresentam temperaturas menores ou iguais a $5^{\circ} \mathrm{C}$. A variaçáo de fluxo de veículos durante o "Estação Gramado", apesar das férias escolares não foi muito diferente do mês anterior, só apresentou ligeiro aumento dos fluxos entre as quintas e os domingos. O fluxo total do mês foi 155.435 veículos.

Em agosto de 2012, houve registro de temperatura propícia à neve somente Dia 20. $\mathrm{O} 40^{\circ}$ Festival de Cinema ocorreu entre os dias 10 a 18 , período em que também se registrou o maior fluxo de veículos nas praças de pedágio. O total mensal foi de passantes pelo pedágio foi de 134.505 veículos. 
Em setembro de 2012, houve novamente um fim de semana prolongado em função do feriado da Independência ocorrido na sexta-feira. Este foi também o fim de semana de maior incremento no fluxo de veículos nas praças de pedágio. A ocorrência de temperatura inferior a $5{ }^{\circ} \mathrm{C}$, com previsão de neve, ocorrida Dia 26, não apresenta alteraçáo de fluxo. Setembro entáo é marcado por fluxo padrão, ou seja, máximo nos finais de semana e mínimo nas segundas e terças-feiras, perfazendo um total mensal de 135.549 veículos.

Em termos de movimento anual nos pedágios, constata-se através da Figura 11 que, no ano de 2012, houve um incremento geral no fluxo de veículos leves neste ano. Nos meses de inverno de 2012, com um máximo em julho. O fluxo mensal mais intenso de veículos nos pedágios do entorno de Gramado (192.157veículos) ocorreu no mês dezembro, mês do auge do evento "Natal Luz", efeito que se estende para os meses de novembro e janeiro.

Figura 11 - Fluxo mensal de veículos nas praças de pedágio em 2011

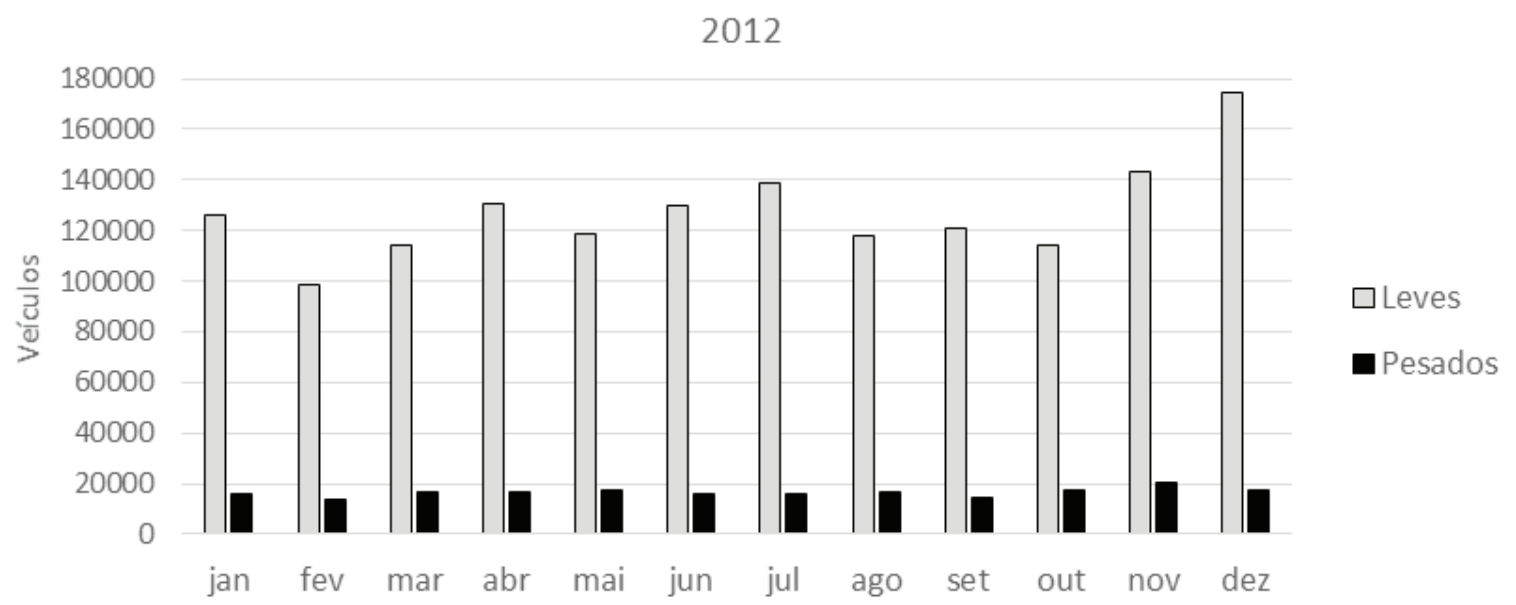

Fonte: Brita Rodovias

Nos anos 1940 a atividade turística em Gramado em nada se assemelhava ao que é o turismo hoje. Tinha como meio de transporte o trem, os empreendedores e a maioria dos turistas eram de origem germânica, os atrativos eram o clima mais ameno no verão, a paisagem e a tipologia de lazer era de veraneio, em balneários voltados a recuperação da saúde, portanto um turismo distante do turismo cultural e de negócios que movimentam o trade turístico da Serra em nossos dias.

Em agosto de 1978, quando Gramado estava se reestruturando para o turismo e no ano em que o Festival de Cinema passou a ganhar maior notoriedade no cenário nacional, ocorreu uma forte nevasca na cidade que chamou turistas de várias cidades do país e do exterior (VALDUGA, 2007, p. 151). Visto que o Brasil é marcado pela dominância do clima tropical, por belas praias e "sol o ano inteiro", Gramado 
se diferencia neste contexto, tanto pela temperatura quanto pela identidade criada anteriormente. Seu clima é marcado pela possibilidade de sentir frio e ocorrência de neve. Assim, segundo Dornelles (2001, p. 115) se cria a imagem de que o frio e a neve são outros produtos a serem consumidos e experienciados em Gramado (Figura 12), sendo responsável por atrair muitos turistas e visitantes, desejosos de fugir do clima típico de suas cidades de origem. Nos meses de inverno são frequentes geadas e nevoeiros, mas a neve é, de fato, um fenômeno raro. Nos quatro anos de análise houve seis ocorrências.

Figura 12 - Bonecos e globo de neve na Estação Gramado 2013
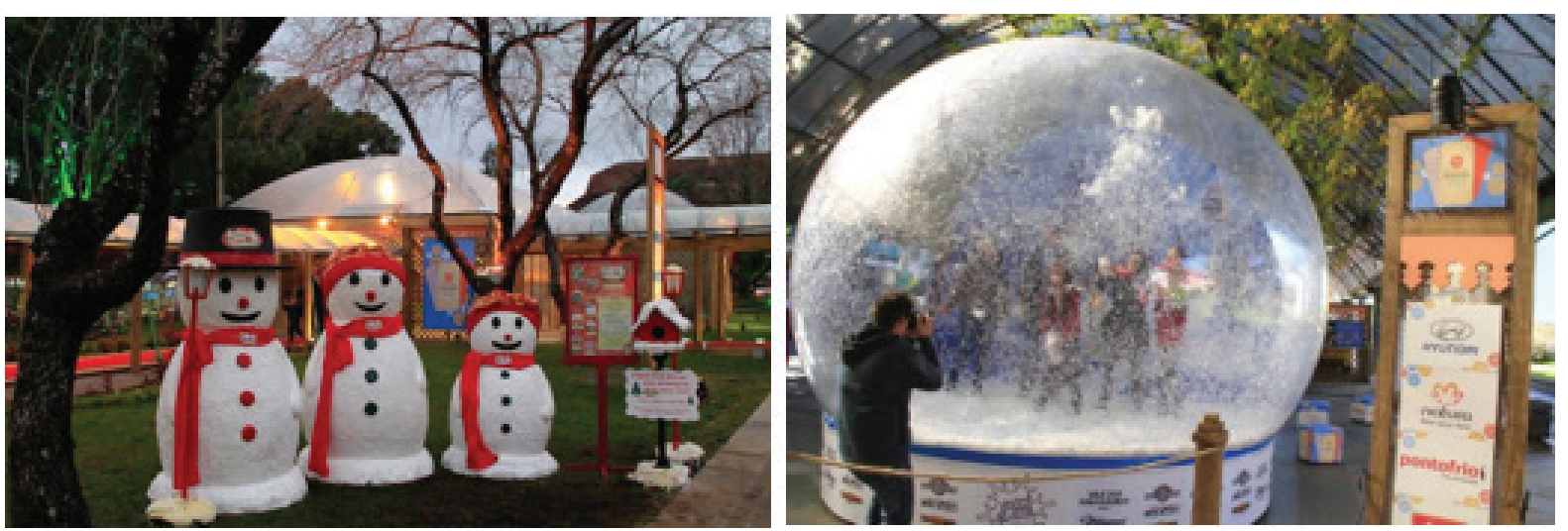

Fonte: Zero Hora, 29/06/2013 e 30/06/2013.

Assim, em Gramado têm-se cada vez mais, com a falsificação do evento neve, o que Milton Santos (1992) considerou o triunfo da apresentação sobre a significação, ainda que, até há alguns anos atrás, as imagens tenham demandado uma sustentação no processo natural e em sua recorrência.

Atualmente, Gramado/Canela destacam-se como o polo turístico do Rio Grande do Sul mais procurado pelo turista brasileiro durante todo o ano e, como destino de inverno, são uma referência para o Brasil. Isto também fica claro no gráfico da figura 13, a linha de tendência mostra que, no geral, os fluxos de veículos de todos os meses do ano cresceram no período o analisado (2009-2012), que o mês de dezembro desponta como de máximo fluxo e que o mês de novembro apresentou um rápido crescimento de fluxo neste período, ficando em 2011 e 2012 à frente de julho, que anteriormente era o segundo mês de maior fluxo. 
Figura 13 - Fluxo total mensal de veículos nas praças de pedágio de 2009 a 2012

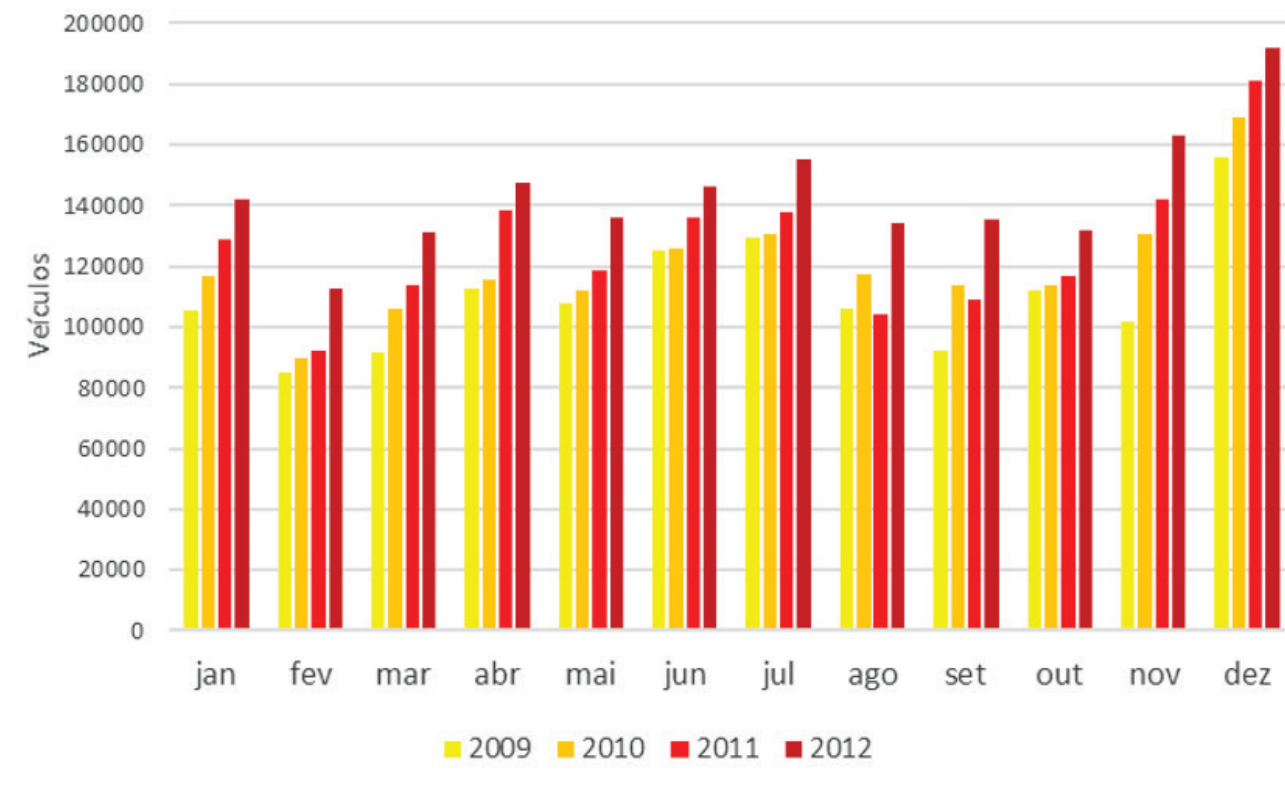

Fonte: Brita Rodovias

Quando turistas chegam a Gramado, esperam presenciar a precipitaçáo de neve, que como divulgam e anunciam os canais de comunicaçáo e propagandas, ocorre frequentemente no período frio do ano. Muitas vezes sáo desapontados pela ausência de neve e, por vezes, até de frio. Em funçáo disso, o trato mercantil do turismo tem criado atrativos em Gramado para suprir essa carência.

Um dos projetos mais recentes foi o "Snowland - Parque da Neve" inaugurado em 2013, que permite que o turista, através de um ingresso adquirido, aprecie os encantos da neve em qualquer estação do ano e sem precisar torcer por condiçóes do tempo favoráveis. Este parque de neve indoor, com mais de 7,2 mil metros quadrados dedicados ao frio, oferece mais de trinta atraçóes aos turistas. Portanto, agora o fenômeno natural está cedendo lugar a neve como artefato.

\section{CONCLUSÃO}

Ao longo do presente trabalho procurou-se estabelecer uma síntese integradora da relaçáo clima x turismo, fundamentada nos dados meteorológicos e de fluxo de veículos do entorno da cidade de Gramado.

Com seu território localizado, boa parte no "Planalto de Neve", Gramado é focalizada pela imprensa em funçáo da ocorrência/possibilidade de neve. O número de dias dos anos com precipitação de neve é fortemente controlado pela elevação do terreno. Segundo Schmitz (2007, p. 50), entre as cotas altimétrica de $600 \mathrm{~m}$ e $900 \mathrm{~m}$, a ocorrência é episódica e difusa, em média com 0,5 dia por ano de precipitação nival. É nesta cota que se encontra 
a cidade de Gramado, com 830m. Em determinadas cidades do Rio Grande do Sul, em altitudes acima dos $900 \mathrm{~m}$, a possibilidade de neve é maior, porém o acesso e a infraestrutura das cidades "limitam" o turismo. A acessibilidade por vias terrestres pavimentadas parece ser o aspecto fundamental para se destacar na mídia e na divulgação do "turismo da neve". Por essa, razáo Gramado acaba polarizando o turismo de inverno no Brasil, como mostrou o prêmio "O melhor de viagens e turismo 2012/2013", na opinião dos leitores da revista VIAGEM E TURISMO, tendo como referências, o frio, as pousadas, os hotéis, a boa comida, a hospitalidade, a possibilidade de compras e a segurança.

A hipótese deste trabalho era de que baixas temperaturas fizessem aumentar significativamente o fluxo turístico para Gramado. Os dados mostraram que temperatura inferior ou igual a $5{ }^{\circ} \mathrm{C}$ pode ocorrer de junho a setembro, de forma náo contínua. $\mathrm{O}$ fluxo de veículos apresenta maiores valores nos finais de semana e feriados chegando próximo aos dez mil veículos em algumas datas, durante o período observado. Segundo a análise dos gráficos de fluxo de veículos justapostos aos de condiçóes meteorológicas para a ocorrência de neve, a relação hipotética não se confirma de modo direto. Houve períodos de baixas temperaturas anunciadas e ocorridas, que realmente fizeram aumentar o fluxo de veículos, no entanto, foram períodos em que também ocorreram feriados mais prolongado, datas comemorativas ou um evento importante na cidade. Baixas temperaturas no início da semana, dificilmente significaram aumento de fluxo.

Em junho o feriado de Corpus Christi e o dia dos Namorados fazem aumentar significativamente o fluxo. No mês de julho a dinâmica de fluxos se intensifica nas segunda e terceira semana, relacionado as férias escolares e o evento "Estação Gramado". Em agosto o fluxo maior ou menor de veículos relaciona-se principalmente aos fins de semana em que ocorre o Festival de Cinema. Nos meses de junho e setembro, o fluxo maior normalmente ocorre no primeiro final de semana após o dia 5, dia de recebimento de salários da maioria das categorias.

Em Gramado, mesmo que a neve não seja um fenômeno frequente, o turista é levado a lembrar dela visualmente. O fenômeno climático se transformou em simbólico, através dos bonecos de neve, da casa do Papai Noel, dos cartóes postais da cidade. Segundo Dorneles (2001, p. 144) a neve passou a ser um ícone de identificação da serra gaúcha e de diferenciação em relação a outras regióes do país, onde este fenômeno não ocorre. Além disso, como não é possível presenciar o fenômeno natural da neve em todo o período de inverno, é preciso lembrar, através da divulgação de imagens, os cenários com neve ainda que estas estejam desatualizados, criar cenários durante este período que se refiram ao fenômeno, como os criados para a "Estação Gramado 2013", ou produzir neve artificial.

Gramado é mais que um destino de inverno, apresenta um grande calendário de eventos atrativos. Mesmo em eventos como o Natal Luz, que determina o maior fluxo de veículos nas praças de pedágio como foi observado, remetem à neve, como as renas, o papai Noel todo enroupado, entre outros elementos. Sendo assim, a neve deixa de ser um fenômeno meteorológico possível de ocorrer no inverno e passa a ser uma possiblidade aditivo-econômico. 


\section{REFERÊNCIAS REFERÊNCIAS}

ARAUJO, L. C. Memória sobre o clima do Rio Grande do Sul. Rio de Janeiro: Diretoria de Meteorologia. 1930. 100p.

BARRETO FILHO, A. Marketing turístico para o espaço urbano: comentários acadêmicos e profissionais. In: CASTROGIOVANNI, A. C.; GASTAL, S. (Orgs.).Turismo urbano: cidades, sites de excitação turística. Porto Alegre: s. n., 1999. pp. 74-83.

BATTAN, Louis J. Precipitation. In: OLIVER, John E. e FAIRBRIDGE, Rhodes.W. The encyclopedia of climatology. Canadá: Van Nostrand. 1987, pp. 688-900

BRITA RODOVIAS. Polo de Concessão Rodoviária de Gramado. Disponível em: <http:// www.britarodovias.com.br/index.php/> Acesso em: 5 mar. 2013.

CLICRBS (Rede Brasil Sul de Comunicaçóes) - Central de Meteorologia. Disponível em:<http://wp.clicrbs.com.br/centraldemeteorologiadarbs >. Acesso em: maio 2013.

DORNELES, Edson B. Gramado: a produção e consumo de uma imagem de cidade europeia no sul do Brasil. 2001. 172 f. Dissertação (Mestrado em Antropologia Social). Instituto de Filosofia e Ciências Humanas, Universidade Federal do Rio Grande do Sul,(UFRGS) Porto Alegre, 2001.

FUENTES, Márcia A. Dinâmica e Padrões da Precipitação de Neve no Sul do Brasil. 2009, 191 f. Tese (Doutorado em Geociências). Instituto de Geociências, Universidade Federal do Rio Grande do Sul (UFRGS), Porto Alegre, 2009.

HAUSMAN, Abrão. Climatologia do Estado do Rio Grande do Sul. Porto Alegre: Secretaria Estadual da Agricultura, 1956. 12p.

IBGE. Cidades. Disponível em:<http://www.ibge.gov.br/cidadesat/index.php> Acesso em: 2 jun 2013.

INMET. Estações automáticas. Disponível em:<http://www.inmet.gov.br/sonabra/maps/ automaticas.php> Acesso em: 2 jun 2013.

. Glossário. Disponível em:<http://www.inmet.gov.br/portal/ > Acesso em: jul.2013.

NERY, Jonas T, CARFAN Ana C. Glossário de termos técnicos em meteorologia e climatologia. Jundiaí: Paco Editorial, 2013. 416p.

SANT'ANNA NETO, João L. A análise geográfica do clima: produção de conhecimento e consideraçóes sobre o ensino. Geografia,Londrina, UEM, v.11,n. 2, pp. 321-328, jul.dez. 2002.

SANTOS, Milton. A redescoberta da Natureza. Estudos Avançados, v. 6 n. 14, pp. 1-15, 1992. Disponível em:<http://www.scielo.br/pdf/ea/v6n14/v6n14a07.pdf > Acesso em: dez. 2016.

SCHMITZ, Cláudio M. A neve no Rio Grande do Sul. 2000. 73 f. Trabalho de Conclusão de Curso. ( ) Instituto de Geociências, Universidade Federal do Rio Grande do Sul (UFRGS), Porto Alegre, 2000. 
. A.Precipitação de neve no Brasil Meridional. 2007. 67f. Dissertação (Mestrado em Geografia). Instituto de Geociências, Universidade Federal do Rio Grande do Sul (UFRGS), Porto Alegre,2007.

SOUZA, Rodolfo. O. Algumas consideraçóes sobre a neve no Brasil. In: SIMPÓSIO DE GEOGRAFIA FÍSICA APLICADA,4., 1991, Porto Alegre.Anais..., v. 1, pp. 469-477.

A Ocorrência de Neve em Planaltos Subtropicais. 1997. 144 f. Dissertação (Mestrado em Geografia). Faculdade de Filosofia e Ciências Humanas, Universidade de São Paulo, São Paulo, 1997.

VALDUGA, M. C. Desmitificando um Modelo de Desenvolvimento: A Formação da Sociedade do Turismo na Periferia do Capitalismo. 2007. Dissertação (Mestrado em Turismo). Universidade de Caxias do Sul, Caxias do Sul, 2007.

VIANELLO, Rubens. L.; ALVES, Adil R. Meteorologia básica e aplicações. Viçosa: UFV, Imprensa Universitária, 1991. 449p.

WOLFF, Nilson p. A neve no Brasil. Porto Alegre: Evangraf, 2005. 388p.

. Causas e consequências da ocorrência de neve nas regiões sul e sudeste do Brasil. 2001. 124 f. Monografia. (Curso de Estudos Sociais - Geografia), UNILASALLE, Canoas, 2001.

ZERO HORA. Especial neve. Disponível em:<http://www.clicrbs.com.br/zerohora/swf/ especial_neve/> Acesso: 8 ago 2013. 